\title{
A Radiocarbon Date from a Middle Caddo period Habitation Site on Hickory Creek, Houston County, Texas
}

Timothy K. Perttula

Heritage Research Center, Stephen F. Austin State University

Follow this and additional works at: https://scholarworks.sfasu.edu/ita

Part of the American Material Culture Commons, Archaeological Anthropology Commons, Environmental Studies Commons, Other American Studies Commons, Other Arts and Humanities Commons, Other History of Art, Architecture, and Archaeology Commons, and the United States History Commons

Tell us how this article helped you.

This Article is brought to you for free and open access by the Center for Regional Heritage Research at SFA ScholarWorks. It has been accepted for inclusion in Index of Texas Archaeology: Open Access Gray Literature from the Lone Star State by an authorized editor of SFA ScholarWorks. For more information, please contact cdsscholarworks@sfasu.edu. 


\section{A Radiocarbon Date from a Middle Caddo period Habitation Site on Hickory Creek, Houston County, Texas}

\section{Creative Commons License}

\section{(c) (1) \&}

This work is licensed under a Creative Commons Attribution-NonCommercial 4.0 International License 


\title{
A RADIOCARBon DATE FROM A MiddLe CADdo PERIOD Habitation Site ON HickoRY CREEK, Houston CounTy, TEXas
}

\author{
Timothy K. Perttula
}

\author{
Introduction
}

The National Forests and Grasslands (U.S.D.A. Forest Service) in Texas (NFGT) conducted Passports in Time (PIT) projects in 2006 and 2007 on Hickory Creek in the Davy Crockett National Forest, Houston County, Texas. The work took place at four prehistoric archeological sites: 41H013, HC-1, Hickory Creek \#2 (HC-2), and HC-3, with the majority of the work occurring at the Hickory Creek \#2 site. Following discussions with the NFGT, the NFGT agreed to turn over the collections and available notes/records to me for the purposes of completing a volunteer analysis of these collections and preparing a report on the analytical findings (Perttula and Nelson 2009).

During the course of the analysis, I learned that a radiocarbon sample of animal bone had been submitted to Beta Analytic, Inc. by the NFGT in 2007, but the dating specifics of that sample were not available until after Perttula and Nelson (2009) completed their report on the Hickory Creek collections. The purpose of this article is to provide the results of the radiocarbon analysis of this one sample, and consider its chronological and cultural implications for prehistoric Caddo sites in this area of East Texas.

\section{Context of the Radiocarbon Sample}

The Hickory Creek \#2 site is located on an alluvial rise (ca. 230 feet amsl) next to an old channel of Hickory Creek. Hickory Creek is an eastward-flowing tributary of the Neches River in the East Texas Pineywoods (Diggs et al. 2006). Hickory Creek merges with the Neches River about $12 \mathrm{~km}$ below the southernmost El Camino Real de los Tejas crossing of the river, and the mouth of the creek is approximately $14 \mathrm{~km}$ from the early Caddo (ca. A.D. 850-1300) mound center at the George C. Davis site (41CE19) (Story 2000; Newell and Krieger 2000). The Hickory Creek sites are about $8 \mathrm{~km}$ upstream from its confluence with the Neches River.

PIT project archeological investigations in 2006 at the Hickory Creek \#2 site included the removal and screening of the fill and back dirt from four looter pits (\#3, 4, 5, and 8). In 2007, seven excavation units (Unit 1-7) of varying sizes were hand-excavated to a maximum depth of $90 \mathrm{~cm}$ bs in the archeological deposits at the site. The units ranged from $2 \times 2 \mathrm{~m}$ in size (Unit 2, 4, and 7) to $3 \times 3 \mathrm{~m}$ in size (Units 1, 3, 5, and 6). Based on placement of units across the landform, Units 1-4 are part of Area A at the site, while Units 5-7 are in Area B (Figure 1). During the excavations, no obvious features were encountered in the archeological deposits, but a concentration of ceramic sherds, animal bones, and other domestic refuse was noted between $30-40 \mathrm{~cm} \mathrm{bs}$ that may represent an occupational surface or the unprepared floor to a prehistoric Caddo house structure. A sample of unburned animal bones from Unit $3(29-35 \mathrm{~cm}$ bs) in Area A was submitted to Beta Analytic, Inc., for radiocarbon dating. Unit 3, as with other excavation units (Table 1), contained an abundance of lithic debris, chipped stone tools, plain and decorated ceramic sherds, burned clay/daub, and animal bones ( $\mathrm{n}=334$, Perttula and Nelson 2009:Table 18).

At the Hickory Creek \#2 site, there are high densities of prehistoric archeological materials across the landform, particularly in Units 1, 3-6 and Looter Pit 8. In the western part of the site, the highest density of arrow points is in Unit 3. This same unit has the highest densities per $\mathrm{m}^{2}$ in plain sherds, decorated sherds, and burned clay/daub. Furthermore, the western area of the site, along with Unit 4, have the highest densities of sherds in the archeological deposits, ranging from 5.4-26.5 sherds per $\mathrm{m}^{2}$, compared to only 0.1-3.6 sherds per $\mathrm{m}^{2}$ in Area B at the eastern end of the site (see Figure 1). 


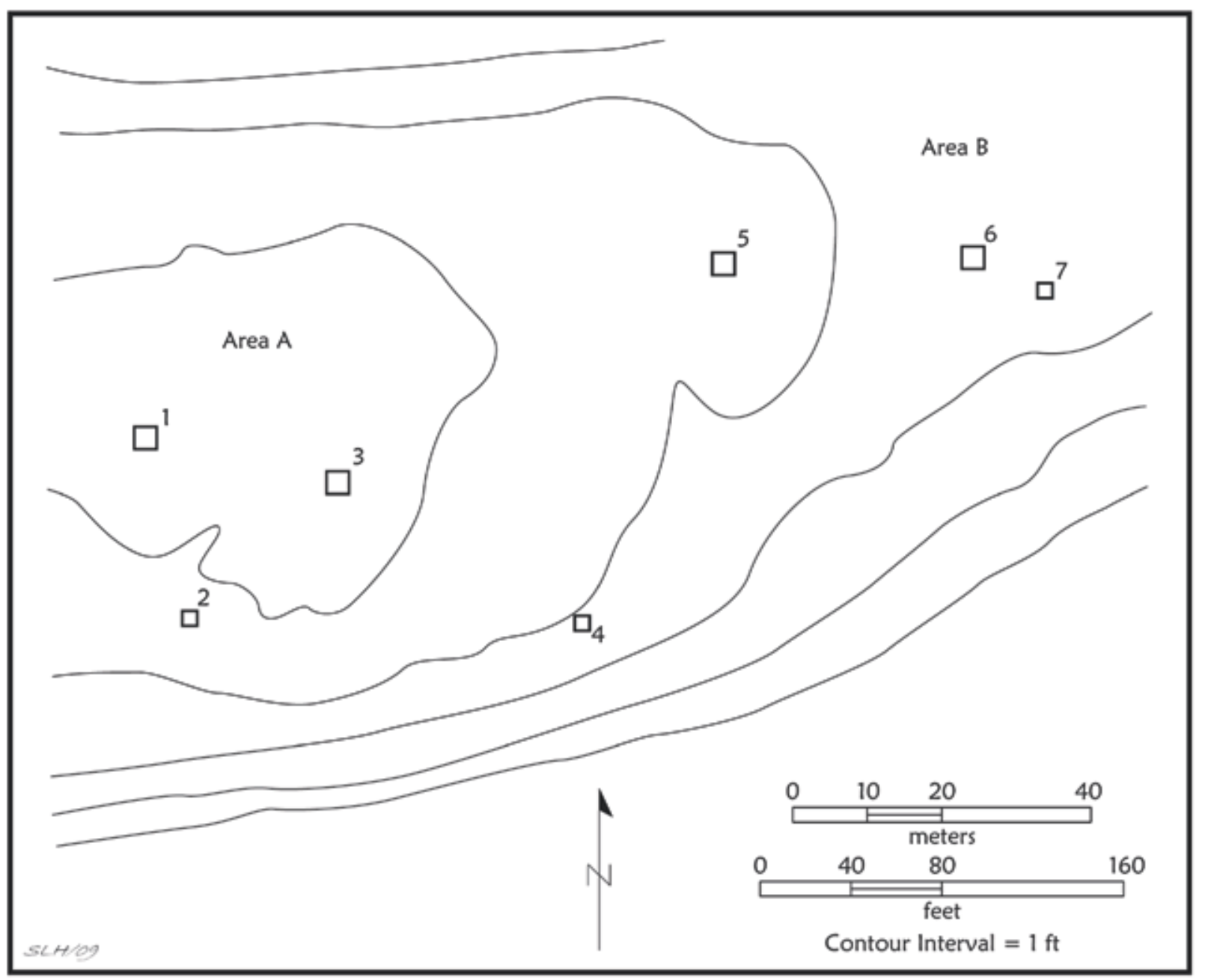

Figure 1. Map of the Hickory Creek \#2 site and the location of Units 1-7. Map prepared by Sandra Hannum.

Table 1. Prehistoric artifacts from the Hickory Creek \#2 site units and looter pits (LP).

\begin{tabular}{lrrrrrrrrrrr}
\hline \hline Unit & DP & BIF & \multicolumn{1}{c}{ AP } & FT & \multicolumn{1}{c}{ LD } & FCR & GS & PS & DS & BC/D & N \\
\hline 1 & 18 & 4 & 2 & 9 & 1567 & 20 & 6 & 34 & 14 & 5 & 1679 \\
2 & 6 & 3 & 3 & 4 & 692 & 5 & 3 & 20 & 12 & - & 748 \\
3 & 4 & 3 & 13 & 4 & 1363 & 4 & 2 & $141+$ & 97 & 43 & 1674 \\
4 & 12 & 19 & 5 & 9 & 2602 & 11 & 2 & 35 & 8 & 4 & 2707 \\
5 & 9 & 5 & 2 & 6 & 1400 & 6 & 2 & - & 1 & 2 & 1433 \\
6 & 14 & 11 & 5 & 7 & 1233 & 17 & 2 & $25^{*}$ & 7 & - & 1321 \\
7 & - & - & 1 & - & 276 & - & - & - & - & - & 277 \\
& & & & & & & & & & & \\
LP3 & 8 & - & 2 & 1 & 180 & 5 & - & 10 & 1 & 3 & 210 \\
LP4 & 1 & & - & - & 39 & - & - & 1 & 1 & - & 42 \\
LP5 & - & 1 & - & 1 & 236 & 5 & 1 & 13 & 1 & - & 258 \\
LP8 & 6 & 3 & 1 & 4 & 775 & 5 & - & 13 & 2 & 1 & 810 \\
Total & $\mathbf{7 8}$ & $\mathbf{4 9}$ & $\mathbf{3 4}$ & $\mathbf{4 5}$ & $\mathbf{1 0 3 8 1}$ & $\mathbf{7 8}$ & $\mathbf{1 8}$ & $\mathbf{2 9 2}$ & $\mathbf{1 4 4}$ & $\mathbf{5 8}$ & $\mathbf{1 1 1 7 7}$ \\
\hline
\end{tabular}

$\mathrm{DP}=$ dart point; $\mathrm{BIF}=$ biface; $\mathrm{AP}=$ arrow point; $\mathrm{FT}=$ flake tool; $\mathrm{LD}=$ lithic debris and cores; $\mathrm{FCR}=$ firecracked rock; GS=ground stone tool; PS=plain sherd; DS=decorated sherd; BC/D=burned clay/daub *includes one plain pipe sherd; +includes five plain pipe sherds 
By depth, there is a stratigraphic division between the upper Caddo archeological deposits (0-40 to 50 $\mathrm{cm}$ bs) and the lower Woodland and Late Archaic archeological deposits (40 to 50-90 cm bs) in the character of the recovered prehistoric ceramic and lithic artifacts (Table 2). The radiocarbon sample was clearly collected from buried Caddo archeological deposits.

Plain and decorated ceramic sherds are concentrated between 10-50 cm bs (where they comprise between 4.6-6.7\% of all the artifacts in those levels) in the Caddo archeological deposits at the Hickory Creek \#2 site (see Table 2). In the lowermost archeological deposits, sherds by level account for only 1.2-2.5\% of the artifacts; in some measure, these are not Caddo sherds displaced from the upper archeological deposit, but Woodland period sherds (plain sandy paste Goose Creek Plain, var. unspecified sherds) from an earlier, and deeper, prehistoric occupation. Burned clay/daub is concentrated between 20-50 cm bs (see Table 2). Dart points are found throughout the archeological deposit-which suggests the movement and mixing of artifacts by bioturbation as well as slow aggradation of these alluvial deposits-but they are concentrated from 40-90 $\mathrm{cm}$ bs; arrow points are concentrated from 0-30 cm bs.

Table 2. Prehistoric artifacts from the Hickory Creek \#2 site by depth, all units.

\begin{tabular}{|c|c|c|c|c|c|c|c|c|c|c|c|}
\hline $\begin{array}{l}\text { Depth } \\
\text { (cm bs) }\end{array}$ & DP & $\mathrm{BIF}$ & AP & FT & LD & FCR & GS & PS & DS & $\mathrm{BC} / \mathrm{D}$ & $\mathrm{N}$ \\
\hline \multicolumn{12}{|c|}{ Suggested upper archeological deposits } \\
\hline $0-10$ & - & 1 & 6 & - & 630 & - & - & $14^{*}$ & 6 & 1 & 658 \\
\hline $10-20$ & 4 & 5 & 8 & 1 & 1299 & 1 & - & $47^{*}$ & 36 & 4 & 1405 \\
\hline $20-30$ & 3 & 4 & 10 & 5 & 1451 & 2 & 1 & $60+$ & 48 & 19 & 1603 \\
\hline $30-40$ & 1 & 4 & 2 & 2 & 1077 & 7 & 2 & $34^{*}$ & 19 & 14 & 1162 \\
\hline $40-50$ & 11 & 6 & 2 & 2 & 1163 & 2 & - & $43^{*}$ & 14 & 11 & 1254 \\
\hline \multicolumn{12}{|c|}{ Suggested lower archeological deposits } \\
\hline $50-60$ & 9 & 4 & 2 & 9 & 990 & 13 & 3 & 23 & 2 & 1 & 1056 \\
\hline $60-70$ & 16 & 8 & - & 12 & 969 & 15 & 4 & 21 & 5 & - & \\
\hline \multicolumn{12}{|l|}{1050} \\
\hline $70-80$ & 13 & 11 & - & 6 & 906 & 13 & 3 & 10 & 2 & 3 & 967 \\
\hline 80-90 & 6 & 3 & 1 & 1 & 554 & 9 & 4 & 1 & 6 & 2 & 587 \\
\hline
\end{tabular}

$\mathrm{DP}=$ dart point; $\mathrm{BIF}=$ biface; $\mathrm{AP}=$ arrow point; $\mathrm{FT}=$ flake tool; $\mathrm{LD}=$ lithic debris and cores; FCR=firecracked rock; GS=ground stone tool; $\mathrm{PS}=$ plain sherd; DS=decorated sherd; BC/D=burned clay/daub *includes a plain pipe bowl; +includes two plain pipe sherds

\section{Calibrated Radiocarbon Date}

The radiocarbon analysis on animal bone (-21.3\% 13C/12C ratio, probably from deer) from Unit 3 at the Hickory Creek \#2 site yielded a conventional radiocarbon age of $570 \pm 40$ years B.P. (A.D. 1340-1420). The INTCAL04 calibration (Reimer et al. 2004) employed by Beta Analytic, Inc. indicated that the sample had a cal AD 1400 intercept, 1 sigma age ranges of cal AD 1320-1350 and AD 1390-1420, and a 2 sigma age range of cal AD 1300-1430.

Since that time, a new radiocarbon age calibration curve, IntCal09, has been published by Reimer et al. (2009). The IntCal09 calibration for the Hickory Creek \#2 sample has a cal AD 1408 intercept, a 1 sigma age range of cal AD 1389-1414, and a 2 sigma age range of cal AD 1377-1434. By either calibration curve, the radiocarbon age from the Hickory Creek \#2 site falls primarily in the Middle Caddo period (ca. A.D. 1200-1400) and the beginning of the Late Caddo period (ca. A.D. 1400-1650) in East Texas (cf. Story 1990). 


\section{Chronological and Cultural Implications}

Although only one radiocarbon date has been obtained from the Hickory Creek \#2 site, there still is a 95 percent confidence interval that the Caddo archeological deposits at the site (or at last Area A) date between AD 1377-1434. The associated material culture from this prehistoric Caddo site includes plain ware, utility ware, and fine ware pottery sherds; both long-stemmed and elbow pipe sherds; burned clay/daub; primarily Perdiz and Perdiz-Bonham arrow points; expedient flake tools, two scrapers, and one drill; and a few ground stone tools, including a chunk of ochre (Perttula and Nelson 2009).

The plain sherds include 21 rims (one with a lip tab), 186 body sherds, and 21 base sherds. The proportion of plain ware rims to decorated rims from fine ware and utility ware vessels is 21: 20, indicating that plain ware vessels are as common as decorated vessels in the Hickory Creek \#2 ceramic vessel assemblage. Plain ware vessels include bowls, carinated bowls, and jars. At the nearby and generally contemporaneous Hargrove Lake site (41H0150), Jurney (2000:57 and Tables 12 and 13) estimated that there were a minimum of 30 vessels represented in the 374 sherds in the assemblage. Only about $13 \%$ of these vessels were thought to be plain.

The plain to decorated sherd ratio (P/DR), a useful chronological measure in some instances in East Texas Caddo sherd assemblages (see Perttula 2004:390), is 1.63 (i.e., 38\% of the tempered Caddo pottery sherds are decorated). This is consistent with other $13^{\text {th }}$ to mid $-15^{\text {th }}$ century Caddo assemblages in the Neches-Angelina and middle Sabine River basins. Post-A.D. 1450-1650 Caddo sherd assemblages in these areas typically have P/ DR that range from 0.56-1.03. On Historic Caddo ceramic assemblages on San Pedro Creek, P/DR values range between very low values of 0.31-0.32 (Perttula and Nelson 2006:62).

The utility ware sherds from the Hickory Creek \#2 site are dominated by brushed jars, probably of the Bullard Brushed type or an unnamed brushed predecessor. Approximately $67 \%$ of the utility wares have brushed decorations, either as the sole decoration, or in combination with roughened, punctated, incised, or grooved elements, including $40 \%$ of the rims (Table 3 ). The ubiquity of brushed pottery in the utility wares is an apparent characteristic feature of Middle Caddo pottery in this part of the Neches River basin (Jurney 2000; Perttula and Nelson 2006). One of these Middle Caddo sites is the Butler Branch site (41HO216), which has been dated to (2 sigma) cal AD 1200-1290 (Perttula and Nelson 2006:57), and the ceramics here are predominantly brushed utility wares. Incised vessels are also an important part of the Hickory Creek \#2 utility ware assemblage, as they comprise $40 \%$ of the rims and $14.8 \%$ of all the utility ware sherds (Table 3 ). The four incised rims have sets of horizontal incised lines encircling the upper part of the rim, while body sherds primarily have cross-hatched lines $(n=2)$ and closely- to widely-spaced parallel lines $(n=5)$.

Table 3. Utility ware sherds from the Hickory Creek \#2 site.

\begin{tabular}{lccc}
\hline Decorative Method & Rim & Body & Percentage \\
\hline Brushed & 4 & 63 & 58.3 \\
Roughened-Brushed & - & 1 & 0.9 \\
Brushed-Punctated & - & 6 & 5.2 \\
Brushed-Incised & - & 2 & 1.7 \\
Brushed-Grooved & - & 1 & 0.9 \\
Incised-Punctated & 1 & 8 & 7.8 \\
Incised & 4 & 13 & 14.8 \\
Punctated & 1 & 9 & 8.7 \\
Pinched & - & 2 & 1.7 \\
Totals & $\mathbf{1 0}$ & $\mathbf{1 0 5}$ & $\mathbf{1 0 0 . 0}$ \\
\hline
\end{tabular}

The engraved fine ware sherds $(n=25)$ from the Hickory Creek \#2 site are primarily from several distinctive early decorated styles of Poynor Engraved carinated bowls in Area A (Table 4). Three of the fine ware sherds are from engraved bottles. None of the engraved sherds from the site are either red-slipped or have red or white clay pigments rubbed in the engraved lines. 
Table 4. Decorative elements on fine ware sherds from the Hickory Creek \#2 site.

\begin{tabular}{llll}
\hline Decorative element & Rim & Body & $\mathrm{N}$ \\
\hline
\end{tabular}

\section{Carinated bowls}

Poynor Engraved, var. Cook

Poynor Engraved, var. $B$ (horizontal scroll)

Poynor Engraved, diagonal/hatched lines

$\begin{array}{lll}2 & - & 2 \\ 6 & 2 & 8 \\ 1 & 2 & 3\end{array}$

cross-hatched triangles and negative

triangular zone

horizontal-vertical-diagonal lines

parallel engraved lines

excised zone

single straight engraved line

$\begin{array}{lll} & & \\ - & - & 1 \\ - & 1 & 1 \\ - & 4 & 4 \\ - & 1 & 1 \\ & 2 & 2\end{array}$

\section{Bottles}

opposed engraved lines curvilinear engraved lines

Totals 15 25

There are eight rim and body sherds from a single vessel recovered in Unit 3 in Area $A$ that are identified as Poynor Engraved, Var. B (Figures 2a-c, 3b, d, g, and 4a-d). This vessel, a carinated bowl, has a series of horizontal and vertical interlocking scrolls on the rim panel, as well as sets of vertical or semi-circular lines that divide the scrolls on the panel and diagonal scroll filler elements. Var. B of Poynor Engraved has previously been recognized as an upper Neches River variety from only a few sites (the main reason it has not received a formal variety designation at this time) with early (ca. A.D. 1400-1480) Frankston phase mortuary contexts (Perttula 2009:Figure 6-64 and Table 6-37). The description of several of the Poynor Engraved vessels (Vessels 15, 21, 23) from the Hargrove Lake site (Jurney 2000:64) may also be examples of Poynor Engraved, Var. B. vessels.

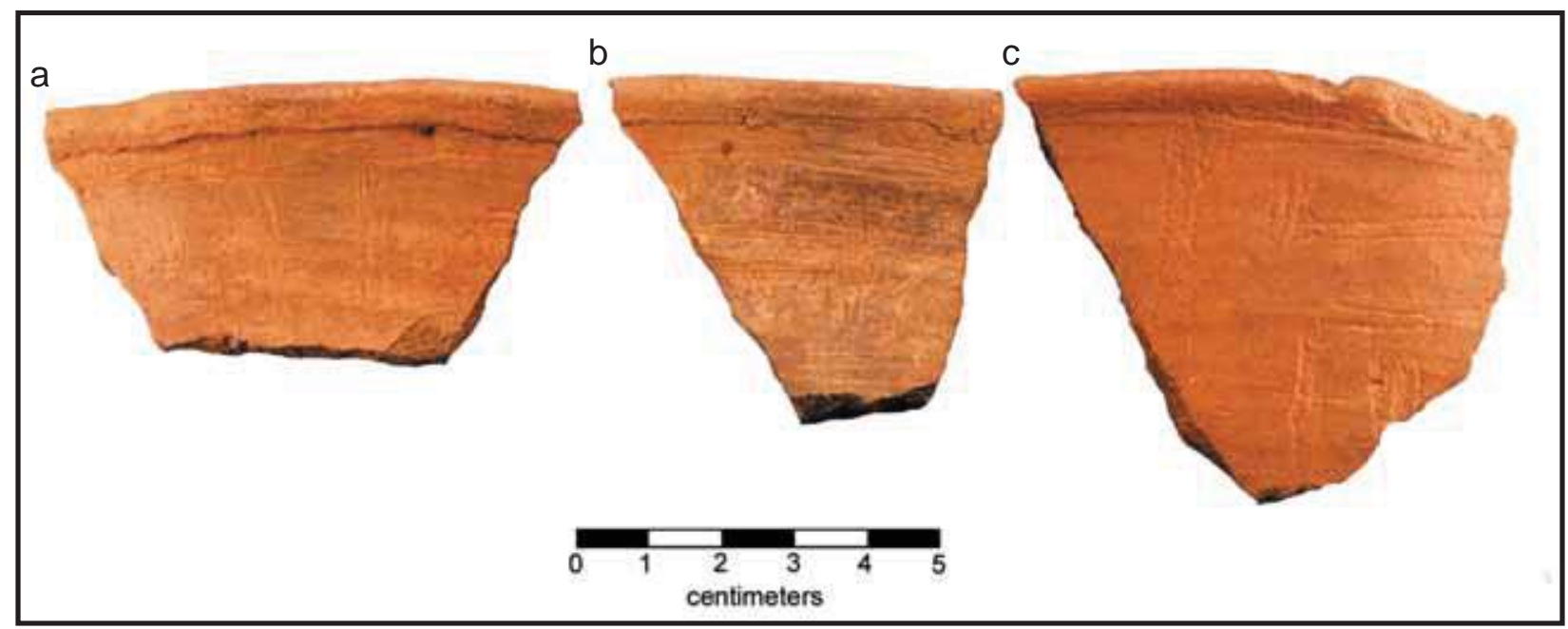

Figure 2. Rim sherds from a Poynor Engraved, var. B vessel (carinated bowl) from the Hickory Creek \#2 site. Provenience: a, c, Unit 3, 20-30 cm bs; b, Unit 3, 30-40 cm bs. 


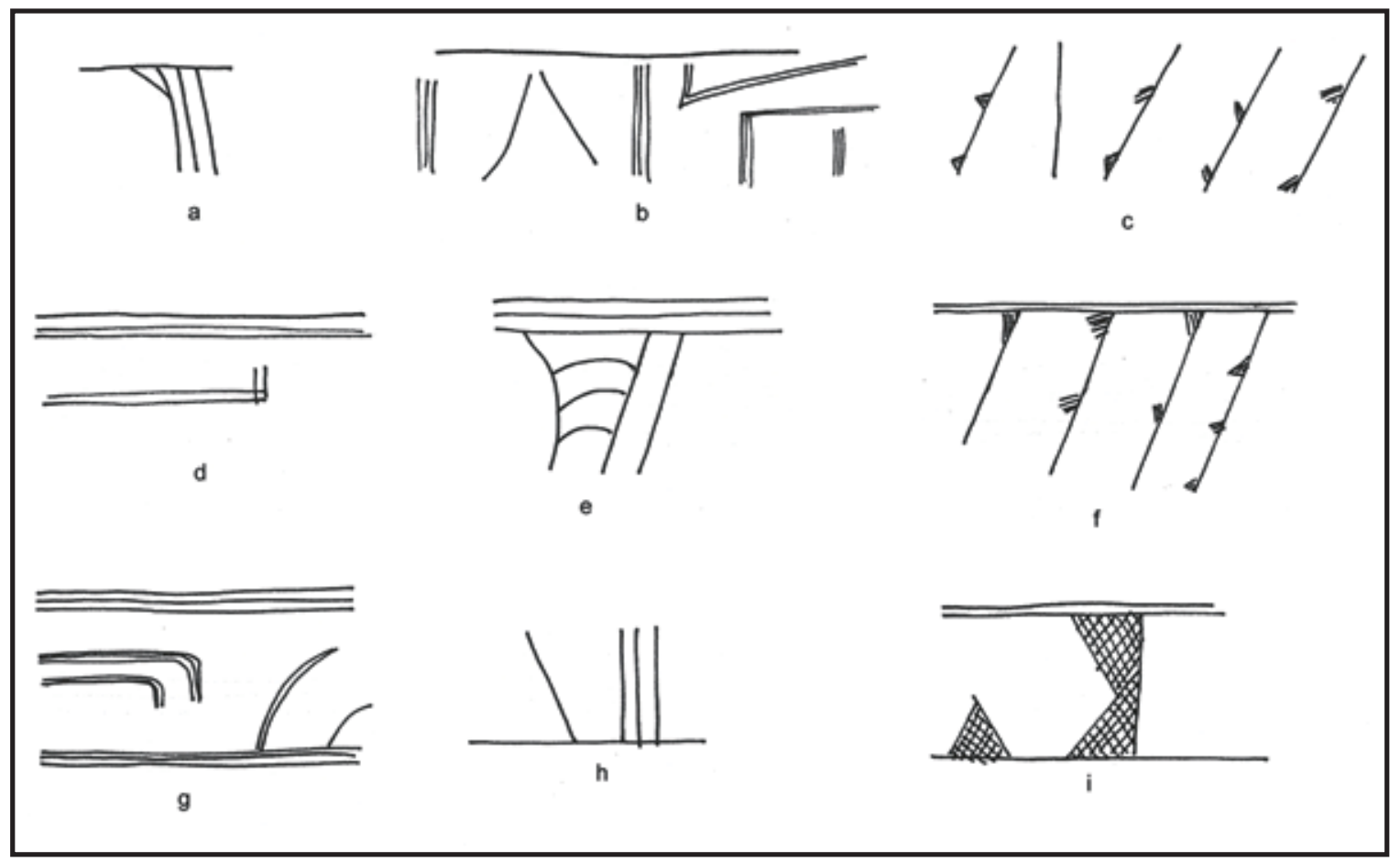

Figure 3. Selected engraved decorative elements in the Hickory Creek \#2 site fine wares: a, Poynor Engraved, var. Cook; b, d, g, Poynor Engraved, var. B; c, f, diagonal engraved; e, cf. Poynor Engraved; h, opposed engraved lines; i, cross-hatched and negative triangle zone.

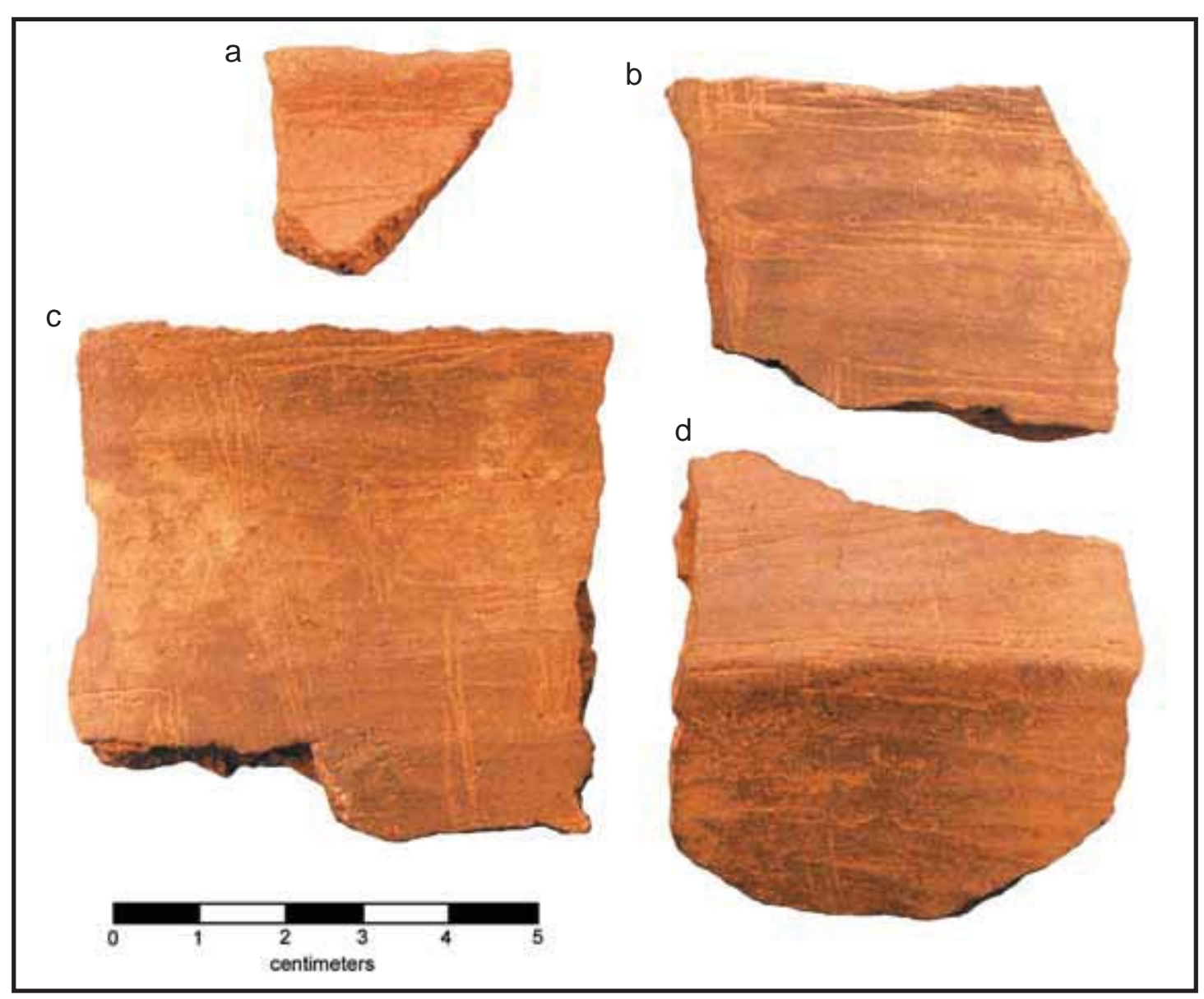

Figure 4. Rim and body sherds from a Poynor Engraved, var. B carinated bowl at the Hickory Creek \#2 site. 
In Area B (Unit 6) are three sherds from another Poynor Engraved carinated bowl. This vessel has a continuous series of diagonal engraved lines on the rim panel, and most of the diagonal lines have small hatched pendant triangles (see Figure 3c, f). This vessel closely resembles another upper Neches River variety, Var. T, of Poynor Engraved, except that the Var. T vessels have small pendant triangles rather than hatched triangles on the diagonal engraved lines (Perttula 2009:Figure 6-64). This particular variety of Poynor Engraved is known from a ca. A.D. 1560-1650 mortuary context in the upper Neches (Perttula 2009:Table 6-37). If this variety of Poynor Engraved has been correctly identified at the Hickory Creek \#2 site, it suggests that the Caddo occupation in Area B postdates the Caddo occupation in Area A by at least 100-150 years.

Poynor Engraved, var. Cook is a recently defined upper Neches River engraved fine ware variety (Perttula 2008:Figure 1d). This variety has multiple sets of engraved ovals on the rim panel, occasionally with hatched areas at the upper and lower corners of each oval. There are two rims of Poynor Engraved, var. Cook from the Hickory Creek \#2 site (see Figure 3a, e), both from Area A.

There is one other distinctive engraved carinated bowl from the Hickory Creek \#2 site. This particular vessel, from Area A, has cross-hatched engraved triangles forming a negative triangular zone (see Figure 3i). Vessel 19 at the Hargrove Lake site has a triangular panel filled with cross-hatched engraved lines (Jurney 2000:64).

The remaining engraved sherds fall into three groups. The first group is body sherds from carinated bowls with simple geometric elements that have parallel, opposed, and straight lines in orientation. The second group consists of a single body sherd with a rectangular panel defined by sets of vertical engraved lines (see Figure 3h), reminiscent of Poynor Engraved, var. Blackburn (see Perttula 2008:Figure 1a). The third group includes three body sherds from bottles with either opposed $(n=1)$ or curvilinear $(n=2)$ engraved lines.

There are six pipe sherds from the Hickory Creek \#2 site. Five are plain bowl and stem sherds from bone-tempered Red River style long-stemmed pipes, which were made by the Caddo from ca. A.D. 800 to the early $15^{\text {th }}$ century A.D (see Hoffman 1967); these long-stemmed pipes are likely from the latest Haley variety. These five Red River pipe sherds are from $10-50 \mathrm{~cm}$ bs in Unit 3, the one area on the site with concentrated Middle Caddo period habitation deposits. The other pipe sherd is from Unit $6(0-10 \mathrm{~cm} \mathrm{bs})$ in Area B. The first use of clay elbow pipes in the Neches River basin began in the mid- $14^{\text {th }}$ century A.D. (Perttula 2009), and they became increasingly popular after that time, eventually replacing the long-stemmed Red River pipes.

The post-ca. A.D. 1200-1300 arrow points at the Hickory Creek \#2 site are dominated by Perdiz points $(\mathrm{n}=14)$ in both Area A and B. Perdiz points have been found in East Texas Caddo sites that date from the $13^{\text {th }}$ to the $17^{\text {th }}$ century A.D., but as of yet, no temporally distinctive varieties of the type have been defined. The dated assemblage of Perdiz points from the Hickory Creek \#2 site may be useful in that regard.

The one Perdiz-Bonham point from the site has a narrow parallel to contracting stem and a flat base. It resembles a style of arrow points recovered from post-A.D. 1200 to ca. A.D. 1300 burial features at the George C. Davis site (see Shafer 1973) as well as at other sites of Middle Caddo period age where possible Alba, Bonham, and Perdiz arrow point forms seem to co-occur or be contemporaneous (Cliff and Perttula 2002:84-85 and Figure 30c, e, i; Perttula and Nelson 2003:114-115 and Figure 4.11a-e). Shafer (1973:207 and Figure 17Z-T1) noted that "most specimens fall within the Alba range but certain specimens clearly fall into the Perdiz type as well. The variation from one type to the other is indeed gradual and to separate one from the other would imply a distinction that does not visibly exist." It is suspected that there are gradual changes in the form of certain stemmed arrow points through time (from ca. A.D. 1200 to the $15^{\text {th }}$ century), leading from what is called the Alba type, to the Bonham type, to that of the Perdiz type, with subtle differences in stem shape, basal form, and shoulder/barb margins, and these morphological changes are probably also associated with changes in raw material use for arrow points. The Perdiz-Bonham arrow point from the Hickory Creek \#2 site fall within the continuous evolutionary development of certain stemmed Caddo arrow points, sharing attributes of both Alba and Perdiz points, as well as Bonham and Bassett points, but lacking a prominent contracting stem. Shafer (2007:Figure 1a-c, 2008:Figure 1g-m) refers to many of these from $14^{\text {th }}$ and early $15^{\text {th }}$ century sites in Smith County, Texas, as "Perdiz-Bassett," but the moniker "Perdiz-Bonham" (Perttula 2008, ed.:450) is preferred because the character of the stem on these points is much more like that of a Bonham than the small pointed and contracting stem of Bassett points (see Turner and Hester 1999:201-202). 
Considering the gamut of recovered artifacts from the site, in both Areas A and B, the prehistoric use of the Hickory Creek \#2 site is temporally complex, probably because it was a favorable location and landform setting for repeated and redundant use. The recovered artifacts from the site indicate that it was used for activities during the Paleoindian, Middle Archaic, Late Archaic, Woodland (Mossy Grove), Early Caddo, $14^{\text {th }}$ to early $15^{\text {th }}$ century Middle Caddo, and Late Caddo ( $16^{\text {th }}$ to mid- $17^{\text {th }}$ century) periods (Perttula and Nelson 2009). The principal occupations at the site (i.e., the occupations that resulted in the most substantial accumulation of archeological materials) occurred first in the Woodland period (ca. A.D. 200-700), and then a number of centuries later, as attested to by the one radiocarbon date, by Caddo peoples in the $14^{\text {th }}$ to early $15^{\text {th }}$ century A.D.

There are spatial differences in the use of the Hickory Creek \#2 site. Temporally diagnostic lithic and/ or ceramic artifacts from Area B (see Figure 2) in the eastern part of the site testify to aboriginal use during Paleoindian, Middle Archaic, Late Archaic, Woodland, and Late Caddo periods. The Woodland occupation and the undated Late Caddo (Perdiz arrow points, later Poynor Engraved styles, elbow pipe sherds) Frankston phase occupation were the most substantial that occurred in Area B, suggesting a relatively intensive use for habitation and various domestic-related activities, but nowhere comparable in apparent intensity and/or duration of use as the Woodland and Middle Caddo occupations in Area A at the site.

In Area $A$ at the western part of the site (see Figure 1), where a single calibrated radiocarbon age range of AD 1377-1434 has been obtained, there are dense accumulations of both Woodland and Middle Caddo archeological materials-much denser here than elsewhere at the site-such that it seems clear that Area A was the locus of a Middle Caddo domestic occupation. It is suspected that there is at least one farmstead compound in Area A (in the immediate vicinity of Unit 3). During the Middle Caddo component in Area A at the Hickory Creek \#2 site, the knapping of chipped stone arrow points (Perdiz) and flake tools was important, as was the manufacture and use of a domestic ceramic assemblage comprised of cooking jars, bottles, and serving vessels (the latter early forms of Poynor Engraved). These Caddo peoples also made and used long-stemmed Red River style clay pipes.

With the completion of the analysis of the artifacts recovered at the Hickory Creek \#2 site (especially those from Area A), and now the publication of the calibrated radiocarbon date from prehistoric Caddo archeological deposits in Area A, the archeological character of the Middle Caddo period in this part of the Neches River basin is coming into focus. Continuing investigations, along with additional radiocarbon dates, of the Hickory Creek \#2 site, promises to contribute more temporally discrete archeological evidence of the material culture character of a Middle Caddo period occupation in East Texas, as well as substantive information on the range of habitation features present in the component. Combining and comparing these archeological data sets from the Hickory Creek \#2 with comparative information obtained recently from other Middle Caddo sites in East Texas (see Middlebrook 1994; Perttula 2008, ed., 2009; Perttula et al. 2009; Shafer 2007, 2008; Walters 2008), should result in a much better understanding of the prehistory of Caddo peoples in the region between ca. 600-800 years ago.

\section{Acknowledgements}

I would like to thank Barbara Williams (U.S. Forest Service, National Forests \& Grasslands in Texas, Lufkin) for providing the opportunity to work on the important collections from the Hickory Creek sites, and for providing the information about the radiocarbon date from the Hickory Creek \#2 site. 


\section{References Cited}

Cliff, M. B. and T. K. Perttula

2002 Results of National Register Investigations Conducted on Site 41PN175, Panola County, Texas. Report No. 32. Archeological Studies Program, Texas Department of Transportation, Austin.

Diggs, G. M., Jr., B. L. Lipscomb, M. D. Reed, and R. J. O'Kinnon

2006 Illustrated Flora of East Texas. Botanical Research Institute of Texas, Fort Worth.

Hoffman, M. P.

1967 Ceramic Pipe Style Chronology Along the Red River Drainage in Southwestern Arkansas. The Arkansas Archeologist 8(1):4-14.

Jurney, D. H.

2000 Archaeological Investigations at the Hargrove Lake Site (41HO150), Davy Crockett National Forest, Houston County, Texas: 1997 Season. United States Department of Agriculture, Forest Service, Lufkin, Texas.

Middlebrook, T.

1994 An Update of Archaeological Investigations at the Tyson Site (41SY92). Journal of Northeast Texas Archaeology 3:1-36.

Newell, H. P. and A. D. Krieger

2000 The George C. Davis Site, Cherokee County, Texas. $2^{\text {nd }}$ Edition. Society for American Archaeology, Washington, D.C.

Perttula, T. K.

2004 The Prehistoric and Caddoan Archeology of the Northeastern Texas Pineywoods. In The Prehistory of Texas, edited by T. K. Perttula, pp. 370-407. Texas A\&M University Press, College Station.

2008 Trends and Varieties in Late Caddo and Historic Caddo Fine Ware Pottery Types in the Upper Neches River Basin. Journal of Northeast Texas Archaeology 28:51-55.

2009 The Ceramic Artifacts from the Lang Pasture Site (41AN38) and the Place of the Site within an Upper Neches River Basin Caddo Ceramic Tradition. In Archeological Investigations at the Lang Pasture Site (41AN38) in the Upper Neches River Basin of East Texas, assembled and edited by T. K. Perttula and D. B. Kelley, pp. 6-1 to 6-260. Coastal Environments, Inc., Baton Rouge.

Perttula, T. K. (editor)

2008 Lake Naconiche Archeology, Nacogdoches County, Texas. Results of the Data Recovery Excavations at Five Prehistoric Archeological Sites. 2 Vols. Report of Investigations No. 60. Archeological \& Environmental Consultants, LLC, Austin.

Perttula, T. K. and B. Nelson

2003 The Nawi haia ina Site (41RK170): Archeological Investigations in the City of Henderson's Southside Wastewater Treatment Plant, Rusk County, Texas. Report of Investigations No. 51. Archeological \& Environmental Consultants, LLC, Austin.

2006 Test Excavations at Three Caddo Sites at Mission Tejas State Park, Houston County, Texas. Report of Investigations No. 76. Archeological \& Environmental Consultants, LLC, Austin.

2009 Prehistoric Artifact Assemblages from Sites along Hickory Creek in the Davy Crockett National Forest, Houston County, Texas. Special Publication No. 14. Friends of Northeast Texas Archaeology, Austin and Pittsburg. 


\section{References Cited (cont.)}

Perttula, T. K., B. Nelson, and M. Walters

2009 Caddo Ceramic and Lithic Artifacts from the Washington Square Mound Site (41NA49) in Nacogdoches County, Texas: 1985 Texas Archeological Society Field School Investigations. Bulletin of the Texas Archeological Society 80:145-193.

Reimer, P. J., M. G. L. Baillie, E. Bard, A. Bayliss, J. W. Beck, C. J. H. Bertrand, P. G. Blackwell, C. E. Buck, G. S. Burr, K. B. Cutler, P. E. Damon, R. L. Edwards, R. G. Fairbanks, M. Friedrich, T. P. Guilderson, A. G. Hogg, K. A. Hughen, B. Kromer, F. G. McCormac, S. W. Manning, C. Brock Ramsey, R. W. Reimer, S. Remmele, J. R. Southon, M. Stuiver, S. Talamo, F. W. Taylor, J. van der Plicht, and C. E. Weyhenmeyer

2004 IntCal04 Terrestrial Radiocarbon Age Calibration, 26-0 ka BP. Radiocarbon 46:1029-1058.

Reimer, P. J., M. G. L. Baillie, E. Bard, A. Bayliss, J. W. Beck, P. G. Blackwell, C. Bronk Ramsey, C. E. Buck, G. S. Burr, R. L. Edwards, M. Friedrich, P. M. Grootes, T. P. Guilderson, I. Hajdas, T. J. Heaton, A. G. Hogg, K. A. Hughen, B. Kromer, F. G. McCormac, S. W. Manning, R. W. Reimer, D. A. Richards, J. R. Southon, S. Talamo, C. S. M. Turney, J. van der Plicht, and C. E. Weyhenmeyer

2009 IntCal09 and Marine09 Radiocarbon Age Calibration Curves, 0-50,000 cal BP. Radiocarbon 51:1111-1150.

Shafer, H. J.

1973 Lithic Technology at the George C. Davis Site, Cherokee County, Texas. Ph.D. dissertation, Department of Anthropology, The University of Texas at Austin.

2007 Leaning Rock Site (41SM325) Lithics. Caddo Archeology Journal 16:57-70.

2008 A Study of Chipped Stone Artifacts from the Redwine Site (41SM193), Smith County, Texas. Journal of Northeast Texas Archaeology 27:49-75.

Story, D. A.

1990 Cultural History of the Native Americans. In The Archeology and Bioarcheology of the Gulf Coastal Plain, by D. A. Story, J. A. Guy, B. A. Burnett, M. D. Freeman, J. C. Rose, D. G. Steele, B. W. Olive, and K. J. Reinhard, pp. 163-366. 2 Vols. Research Series No. 38. Arkansas Archeological Survey, Fayetteville.

2000 Introduction. In The George C. Davis Site, Cherokee County, Texas, by H. P. Newell and A. D. Krieger, pp. 1-31. $2^{\text {nd }}$ Edition. Society for American Archaeology, Washington, D.C.

Turner, E. S. and T. R. Hester

1999 A Field Guide to Stone Artifacts of Texas Indians. Gulf Publishing and Taylor Trade Publishing, Lanham, Maryland.

Walters, M.

2008 Life on Jackson Creek, Smith County, Texas: Archeological Investigations of a $14^{\text {th }}$ Century Caddo Domicile at the Leaning Rock Site (41SM325). Caddo Archeology Journal 17:1-114. 